\title{
Locus of control, knowledge, attitude and practice for contraception among adolescents
}

\author{
Lócus de controle, conhecimento, atitude e prática na contracepção entre adolescentes \\ Locus de control, conocimiento, actitud y práctica en la contracepción entre adolescentes
}

Angela Ferreira da Silva'

ORCID: 0000-0002-6540-6402

Maria Helena Baena de Moraes Lopes' ORCID: 0000-0001-7747-1140

'Universidade Estadual de Campinas. Campinas, São Paulo, Brazil.

How to cite this article: Silva AF, Lopes MHBM. Locus of control, knowledge, attitude and practice for contraception among adolescents. Rev Bras Enferm. 2020;73(2):e20170604. doi: http://dx.doi.org/10.1590/0034-7167-2017-0604

Corresponding Author:

Angela Ferreira da Silva E-mail: angelafesi@yahoo.com.br

EDITOR IN CHIEF: Dulce Aparecida Barbosa ASSOCIATE EDITOR: Marcia Magro

Submission: 08-31-2017

Approval: 06-08-2018

\begin{abstract}
Objectives: to assess the relation of the locus of control with the adolescents' knowledge, attitude and practice (KAP). Methods: this is a cross-sectional study with 1,192 high school students. Data were collected using the KAP questionnaire and the Levenson locus of control scale and analyzed by descriptive statistics, Mann-Whitney U test and Kruskal-Wallis $\mathrm{H}$ test. Results: Women presented higher Externality Powerful Others locus of control than man $(p=0.0015)$ and adolescents over 17, higher Externality Chance locus of control $(p=<0.0001)$. Students who used contraceptive methods at the first contraceptive method had higher Externality Powerful Others $(p=0.0107)$ and those who used coitus interruptus, had higher Externality Chance ( $p=0.0013)$. Internality was inversely proportional to the practice in relation to the dimensions of the locus of control. Conclusions: The dimensions of the locus of control were related to some contraceptive practices, but little or no relation to knowledge and attitude.

Descriptors: Contraception; Internal-External Control; Knowledge, Attitude and Practice in Health; Women's Health; Nursing in Public Health.
\end{abstract}

\section{RESUMO}

Objetivos: Avaliar a relação do lócus de controle com conhecimento, atitude e prática (CAP) contraceptiva de adolescentes. Métodos: Trata-se de um estudo transversal, realizado com 1192 estudantes de ensino médio. Os dados foram coletados por meio do questionário CAP e da escala de lócus de controle de Levenson e analisados por estatística descritiva, teste de Mann-Whitney e teste de Kruskal-Wallis. Resultados: As mulheres apresentaram maior Externalidade Outros Poderosos quando comparadas aos homens ( $p=0,0015)$, e os adolescentes acima de 17 anos, maior Externalidade Acaso $(p=<0,0001)$. Os estudantes que fizeram uso de algum método anticoncepcional na primeira relação sexual apresentaram maior Externalidade Outros Poderosos $(p=0,0107)$, e aqueles que usaram coito interrompido maior Externalidade Acaso ( $p=0,0013)$. A Internalidade mostrou-se inversamente proporcional à prática em relação às dimensões do lócus de controle. Conclusões: As dimensões do lócus de controle apresentaram relação com algumas práticas contraceptivas, mas pouca ou nenhuma relação com conhecimento e atitude.

Descritores: Anticoncepção; Controle Interno-Externo; Conhecimento, Atitude e Prática em Saúde; Saúde da Mulher; Enfermagem em Saúde Pública.

\section{RESUMEN}

Objetivos: Evaluar la relación del locus de control con conocimiento, actitud y práctica (CAP) contraceptiva de adolescentes. Métodos: Se trata de un estudio transversal, realizado con 1.192 estudiantes de enseñanza media. Los datos fueron recolectados a través del cuestionario CAP y de la escala de locus de control de Levenson y analizados por estadística descriptiva, prueba de Mann-Whitney y prueba de Kruskal-Wallis. Resultados: Las mujeres presentaron más Externalidad Otros Poderosos cuando comparadas a los hombres $(p=0,0015)$ y los adolescentes mayores de 17 años, más Externalidad Acaso $(p=<0,0001)$. Los estudiantes que hicieron uso de algún método anticonceptivo en la primera relación sexual presentaron más Externalidad Otros Poderosos $(p=0,0107)$ y aquellos que usaron el coito interrumpido, más Externalidad Acaso $(p=0,0013)$. La Internalidad se mostró inversamente proporcional a la práctica en relación a las dimensiones del locus de control. Conclusiones: Las dimensiones del locus de control presentaron relación con algunas prácticas anticonceptivas, pero poca o ninguna relación con el conocimiento y actitud. Descriptores: Anticoncepción; Control Interno-Externo; Conocimiento, Actitud y Práctica en Salud; Salud de la Mujer; Enfermería de Salud Pública. 


\section{INTRODUCTION}

Young people are currently starting their sexual lives early, around 14, often without the use of birth control methods (BCM) ${ }^{(1-4)}$, which increases vulnerability to pregnancy and sexually transmitted infections (STIs) ${ }^{(2)}$. In Brazil, the sexual initiation of university adolescents occurs when they are 16 or $17^{(5-6)}$. According to a study carried out in Piauí State, in the group of students who had already started sexual activity, few had fixed partners. This is a worrying result because relationships with potential partners increase the risks mentioned above ${ }^{(7)}$. Considering they maintain frequent sexual activity, young people take on a risk behavior, especially when they do not use condoms in sexual relations ${ }^{(3)}$.

A study carried out in Nigeria indicates that adolescents have knowledge about sexual health, but the risk behavior assumed by them in terms of contraception is not consistent with these data ${ }^{(8)}$. Contraceptive decision in adolescence, because of little or no previous experience, may result in the choice for low-efficacy methods and have lifelong consequences ${ }^{(9)}$, such as pregnancy or dropout ${ }^{(10)}$, although the decision of quitting studies may occur even before pregnancy, for other reasons.

In addition, certain personality traits contribute to adolescent contraceptive adherence or not, that is, they can lead to different paths in fertility planning (planned or unplanned pregnancies, for example). Conscious sexual behaviors establish healthy and safe behaviors that make individuals responsible for their reproductive life ${ }^{(11)}$.

Once personal and personality traits influence behavior, scales of locus of control are intended to assess who or what are those responsible for controlling a person's life. Therefore, the locus of control may interfere with several behaviors ${ }^{(12)}$.

Identifying the locus of control among high school adolescents and relating it to the knowledge, attitude and contraceptive practice of this population group can contribute to the development of health education strategies for them. Such strategies should also include integrated sex education, prevention of the use of tobacco, alcohol, and other drugs, because they promote safe and healthy sexual behavior.

Moreover, measuring the locus of control and investigating adolescents' knowledge, attitude, and practice regarding the use of the pill and condoms could provide the health team with a broader understanding of sexual and reproductive health in adolescence and support interventions that favor assigning them responsibilities for decision-making, with a view to more effective control of their own lives.

In view of the above and to better investigate these relations, master dissertation research entitled "Locus of control, knowledge, attitude and practice regarding the pill and male condoms among high school adolescents" was developed, of which this article is part.

\section{OBJECTIVES}

To assess the relation of the locus of control with the adolescents' knowledge, attitude and practice (KAP).

\section{METHODS}

\section{Ethical aspects}

For data collection in public high schools in the city of Poços de Caldas, Minas Gerais State, authorization was requested from the Municipal Secretary of Education, the Regional Superintendence of Education and, later, the principals of each school. The research project was approved by the Research Ethics Committee of the State University of Campinas (Universidade Estadual de Campinas - UNICAMP). Considering that, at the time of submission the Brazil Platform (Plataforma Brasil) was not active, there is no record on this Platform.

Research respected all the ethical and legal precepts of research involving human beings, as recommended by Resolution 196/96 of the National Health Council (Conselho Nacional de Saúde - CNS).

\section{Research design, place and period}

This is a cross-sectional study, carried out in the city of Poços de Caldas, Minas Gerais State, placed in the Southwest Region of the state, with an estimated population of 152,435 inhabitants. At the time of data collection, from May to July 2011, there were 23,302 adolescents in the city, 11,491 of them in the age group from 14 to 19 years old ${ }^{(13)}$.

\section{Population, sample, inclusion and exclusion criteria}

The population of the study was made of adolescents enrolled in all public high schools (one municipal and seven from the state) of Poços de Caldas City. Inclusion criteria: students of both sexes, aged from 14 to 19 , and who study during the day (considering the peculiar profile of those who study in the evening, usually workers). Those who refused to participate in the study, who were not present on the days of data collection, and those who did not sign the Informed Consent Form (ICF) or did not completed the questionnaire, were excluded. The Consent Term was not requested because, at the time of research, this document was not required by the Research Ethics Committee.

The initial population consisted of 3,034 students enrolled in public schools, of whom 1,842 were excluded for the following reasons: 747 did not want to participate, were not present at the time of delivery of the ICF or were not aged between 14 and 19; and refusal from the municipal school (464 students). Of the 1,823 students who received the ICF, 620 did not return it or missed the day of data collection and 11 did not return the questionnaires. Thus, 1,192 adolescents participated in research.

For determining the sample size, and aiming at facilitating calculations, the following criteria were considered: an estimated population of 3,000 participants, representing high school adolescents in public schools, a statistical significance level of $5 \%$ and a sampling error of $6 \%$ for a sample stratified by gender, with the same proportion. It resulted in 384 adolescents of each sex $^{(14)}$. The proportion of $50 \%$ was adopted, because it generated the largest sample needed and avoided underestimation. 


\section{Study protocol}

The questionnaire used was "Locus of control, knowledge, attitude and the use of the pill and condoms among university adolescents ${ }^{\prime \prime(9)}$, with the authorization of the respective authors. It is an instrument that provides data on sociodemographic characteristics (age, sex, skin color, religion, paid work, family income, presence of partner and with whom they live), sex life (age of onset of sexual activity, use of BCM at the first sexual intercourse, age of onset of BCMs use, number of pregnancies and influences in the choice of method), knowledge (questions 35-44 and 51-60), attitudes (questions 22-28), and practice (questions 18-21, 2934 and 45-50) related to the use of the pill and male condoms.

The term 'locus of control' was created by Rotter in 1960, in the sense of internal and external control, and later modified by Hanna Levenson, who elaborated three dimensions of control: Internality (subscale I); Externality Powerful Others locus of control (subscale P); and Externality Chance locus of control (subscale C). When participants are evaluated in the dimension Internality it means that they are responsible for controlling all their acts; in the dimension Externality Powerful Others locus of control, that their actions are influenced by people considered powerful/important; and in the dimension Externality Chance locus of control, that their attitudes are imputed to destiny or luck, as a reference to the events of life ${ }^{(15)}$.

Levenson's multidimensional locus of control scale has 24 items and three subscales, with eight items each: Internality Subscale I (Internality Locus of Control); Externality Powerful Others - Subscale P (Powerful Other Locus of Control); and Externality Chance - Subscale C (Chance Locus of Control). The 24 items are presented as a single scale and must be answered on a Likert scale, with five levels of response, namely: fully agree (5), partly agree (4), absolutely in doubt (3), partly disagree (2) and totally disagree (1). To calculate the scores, add up the values of each item in the subscale. For subscale I, items 1, 4, 5, 9, 18, 19, 21, 23 are added. For Subscale P, 3, 8, 11, 13, 15, 17, 20, 22 and for Subscale $C, 2,6,7,10,12,14,16,24$. The scores range from 8 to 40 points: the higher the value, the greater the belief that each respective factor controls the person's life.

To ensure the confidentiality of respondents, each school was identified by an alphabetic code (for example: A, B, C, D and so on). For control and organization purposes, the researcher kept the listing with the codes of the respective schools.

Initial contact with students was made to clarify the objectives of this project. After that, the Informed Consent Form (ICF) was handed in, which should be signed by participants over 18 . Their parents were asked to authorize those who were underage.

In the second moment, adolescents were approached in their classrooms for the application of instruments, with authorization given by the teacher. In the end, they put the completed questionnaire into an envelope identified only by the alphabetical code corresponding to the school. Each card contained a number from 01 to $X$, considering $X$ the total number of students in the class, plus the school code. Information collected was transferred to a database in Microsoft Corporation's Excel, $2007,6.0$ software.

\section{Results analysis and statistics}

For data analysis, "high scores at each scale are interpreted as indicative of a high expectation of control by the corresponding source, but low scores reflect a tendency to disbelieve that source as a controller and do not indicate that the subjects perceive the control coming from another source"(15).

The evaluation of knowledge and practice as for the pill and male condoms was based on the percentage of correct answers. The attitude was evaluated according to the chosen answer, categorizing it as positive or negative.

The sociodemographic characteristics of the sample were analyzed using descriptive statistics. Non-parametric tests, MannWhitney $\mathrm{U}$ test and Kruskal-Wallis $\mathrm{H}$ test were used to evaluate the relation between the locus of control and the following variables: age, sex, color, religion, financial independence, marital status, family income, the first use of contraceptive methods (in the first sexual relation or not) and use of contraceptive methods.

The association of attitude (positive or negative) with the variables described above was assessed by Fisher's exact test.

The correlation between the scores of the locus of control with knowledge and practice was assessed using the Spearman correlation index, considering that values between 0.1 and 0.29 would indicate a weak correlation; from 0.30 to 0.49 , moderate correlation; and equal to or greater than 0.50 , strong correlation $^{(16)}$. On the other hand, the evaluation of the scores of these loci according to the type of attitude (positive or negative) was based on the results of the Mann-Whitney $U$ test. A significance level of $5 \%$ was defined, and the software used for analysis was the SAS (Statistical Analysis System) version 9.2.

\section{RESULTS}

A total of 1,192 high school adolescents enrolled in public schools in Poços de Caldas City, between 14 and 19, participated in the study. The majority $(1,082 ; 90.8 \%)$ were aged between 15 and 17 , and more than half were female $(750 ; 62.9 \%)$, white $(635 ; 53.3 \%)$, catholic $(672$; $56.4 \%$ ) and did not work (789;66.2\%). A significant proportion of adolescents $(1,147 ; 96.2 \%)$ lived with their family. Less than half of these adolescents $(494 ; 41.4 \%)$ had already started sexual activity. Of the group of adolescents who started sexual activity, $54.3 \%$ were female, 43.9\% male, and $1.8 \%$ did not answer if they used condoms or not.

Table 1 shows the relation between the locus of control and adolescents' sex. Female participants showed higher Powerful Others locus of control when compared to males $(p<0.001)$.

In the correlation of the locus of control with age, considering the 1,992 adolescents, those who were over 17 presented greater Externality Chance locus of control $(p=0.0001)$ when compared to those in the age group from 14 to 16 . In relation to the type of contraceptive method used in the first sexual intercourse, adolescents who used coitus interruptus had greater Externality Chance locus of control ( $p=0.0013$ ).

Table 2 shows the relation of the dimensions of the locus of control with the first time using contraceptive methods. Of the 494 adolescents who had already started their sex life, 424 used some BCM at their first sexual intercourse and presented 
greater Externality Powerful Others locus of control ( $p=0.0107)$. 388 adolescents used BCM after their first sexual relation, and they presented greater Externality Powerful Others $(p=0.0217)$ and greater Externality Chance ( $\mathrm{p}=0.0077)$.

The data in Tables 3 and 4 refer to the 494 adolescents who had already started their sex life, stratified by sex and compared to the locus of control.

In this analysis, it was also possible to observe that the female sex presented higher Externality Powerful Others ( $p=0.0015)$ (Table 3).

As for the use of condom and the dimensions of the locus of control in the first sexual intercourse, according to sex, those who used it had a greater Internality $(p=0.0296)$.
The relation of the dimensions of the locus of control with knowledge, attitude and practice was analyzed based on the responses of 494 adolescents. When the scores of the locus of control size were correlated with the percentage of correct responses in the knowledge and practice questions, Internality was inversely proportional to the practice $(p=0.0102$ and $\rho=-0.075)$, that is, the greater the values of Internality, the smaller those of the practice, although the negative correlation observed was weak ${ }^{(16)}$. The knowledge presented a moderate correlation with the practice $(p<0.0001$ and $\rho \neq=0.361$ ) (Table 5 ). As for attitude, there was no association with the dimensions of the locus of control.

Table 1 - Comparison between locus of control and adolescents' sex from public high schools, Poços de Caldas City, Minas Gerais, Brazil, 2011 (N=1192)

\begin{tabular}{|c|c|c|c|c|c|c|c|c|c|c|}
\hline \multirow[t]{2}{*}{ Male } & \multicolumn{9}{|c|}{ Female } & \multirow{2}{*}{$p+$} \\
\hline & $\mathbf{n}$ & Average & SD & Median & & $n$ & Average & SD & Median & \\
\hline Locus I & 443 & 17.5 & 3.9 & 17 & Lócus I & 749 & 17.5 & 3.9 & 17 & 0.4008 \\
\hline Locus P & 443 & 27.5 & 5.3 & 28 & Lócus P & 749 & 29 & 4.9 & 29 & $<0.001$ \\
\hline Locus C & 443 & 27 & 5.1 & 27 & Lócus C & 749 & 27.2 & 5.1 & 27 & 0.5561 \\
\hline
\end{tabular}

Note: Locus I: Internality; Locus P: Externality Powerful Others locus of control; Locus C: Externality Chance locus of control; pt = p value according to Mann-Whitney U test; SD: Standard deviation.

Table 2 - Relation between the dimensions of the locus of control with the first time using contraceptive methods among high school adolescents of public schools, Poços de Caldas City, Minas Gerais, Brazil, $2011(\mathrm{n}=494)$

\begin{tabular}{|c|c|c|c|c|c|c|}
\hline First time using BCM & & $\mathbf{n}$ & Average & SD & Median & $p+$ \\
\hline \multirow[t]{3}{*}{ In the first sexual intercourse } & Locus I & 424 & 17.29 & 4.03 & 17.00 & 0.8313 \\
\hline & Locus $\mathrm{P}$ & 424 & 28.45 & 5.13 & 29.00 & 0.0107 \\
\hline & Locus C & 424 & 26.60 & 4.86 & 27.00 & 0.5856 \\
\hline \multirow[t]{3}{*}{ After the beginning of their sex life } & Locus I & 388 & 17.27 & 4.00 & 17.00 & 0.8502 \\
\hline & Locus $P$ & 388 & 28.56 & 4.88 & 29.00 & 0.0217 \\
\hline & Locus C & 388 & 26.97 & 4.68 & 27.00 & 0.0077 \\
\hline
\end{tabular}

Note: BCM: Control methods; Locus I: Internality; Locus P: Externality Powerful Others locus of control; Locus C: Externality Chance locus of control; $p t=p$ value according to Mann-Whitney U test; SD: Standard deviation.

Table 3 - Dimension of the locus of control of adolescents who had already started their sex life, according to sex, Poços de Caldas City, Minas Gerais, Brazil, $2011(n=494)$

\begin{tabular}{|c|c|c|c|c|c|c|c|c|c|c|}
\hline \multirow[t]{2}{*}{ Male } & \multicolumn{9}{|c|}{ Female } & \multirow{2}{*}{$p+$} \\
\hline & $\mathbf{n}$ & Average & SD & Median & & $\mathbf{n}$ & Average & SD & Median & \\
\hline Locus I & 220 & 17.07 & 3.93 & 17.00 & Locus I & 274 & 17.47 & 3.93 & 17.00 & 0.2638 \\
\hline Locus P & 220 & 27.32 & 5.07 & 28.00 & Locus $P$ & 274 & 28.95 & 4.98 & 29.00 & 0.0015 \\
\hline Locus C & 220 & 26.75 & 4.81 & 27.00 & Locus C & 274 & 26.55 & 4.85 & 27.00 & 0.6275 \\
\hline
\end{tabular}

Note: Locus I: Internality; Locus P: Externality Powerful Others locus of control; Locus C: Externality Chance locus of control; pt = p value according to Mann-Whitney U test; SD: Standard deviation.

Table 4 - Dimension of the locus of control and its relation with the use of condoms at the first sexual intercourse according to sex, Poços de Caldas City, Minas Gerais, Brazil, $2011(\mathrm{n}=494)$

\begin{tabular}{|c|c|c|c|c|c|c|c|}
\hline \multirow[t]{2}{*}{ Locus } & \multicolumn{3}{|c|}{ Without condom } & \multicolumn{3}{|c|}{ With condom } & \multirow{2}{*}{$p \dagger$} \\
\hline & Average & SD & Median & Average & SD & Median & \\
\hline Female & \multicolumn{3}{|c|}{$(n=63)$} & $(n=205)$ & & & \\
\hline Locus I & 16.48 & 3.60 & 16.00 & 17.68 & 3.97 & 18.00 & 0.0296 \\
\hline Locus P & 28.76 & 5.28 & 29.00 & 29.02 & 4.93 & 29.00 & 0.6513 \\
\hline Locus C & 27.83 & 5.31 & 28.00 & 26.26 & 4.65 & 26.00 & 0.0718 \\
\hline Male & \multicolumn{3}{|c|}{$(n=50)$} & $(n=167)$ & & & \\
\hline Locus I & 17.36 & 3.68 & 18.00 & 17.01 & 4.03 & 17.00 & 0.3280 \\
\hline Locus P & 26.44 & 4.39 & 27.00 & 27.67 & 5.24 & 28.00 & 0.0529 \\
\hline Locus C & 26.56 & 4.27 & 27.00 & 26.77 & 5.00 & 27.00 & 0.8622 \\
\hline
\end{tabular}

Note: Locus I: Internality; Locus P: Externality Powerful Others locus of control; Locus C: Externality Chance locus of control; $p+=p$ value according to Mann-Whitney U test; SD: Standard deviation. 
Table 5 - Dimensions of the locus of control and its relation with the knowledge and practice of high school adolescents regarding the pill and condoms, Poços de Caldas City, Minas Gerais, Brazil, 2011 ( $n=494)$

\begin{tabular}{lllll}
\hline & KNOWLEDGE & & PRACTICE \\
$\boldsymbol{p}$ value & $\mathbf{r}_{\mathbf{s}}$ & $\boldsymbol{p}$ value & $\mathbf{r}_{\mathbf{s}}$ \\
\hline Knowledge & - & - & $<\mathbf{0 . 0 0 0 1}$ & 0.361 \\
Practice & $<\mathbf{0 . 0 0 0 1}$ & 0.361 & - & - \\
Locus I & 0.2423 & -0.034 & 0.0102 & -0.075 \\
Locus P & 0.2122 & 0.036 & 0.1537 & 0.042 \\
Locus C & 0.0523 & 0.057 & 0.7652 & 0.009 \\
\hline
\end{tabular}

Note: Locus I: Internality; Locus P: Externality Powerful Others locus of control; Locus C: Externality Chance locus of control; rs = Spearman's rank correlation coefficient.

\section{DISCUSSION}

Overall, results show that the dimensions of the locus of control influence contraception, although no significant correlation of the dimensions of the locus of control with knowledge, attitude and practice assessed by the KAP survey was observed. Some findings differ from previous research ${ }^{(9)}$, which may result from distinct characteristics among the populations studied.

In the correlation of locus of control with age, the adolescents over 17 presented greater External locus of control (Chance) when compared to younger ones. These data corroborate the study carried out with university adolescents, whose results showed that their first relationship occurred between 15 and 17 years old. They do not use BCM, and the contraceptive practice without the use of condom was maintained, leaving the outcomes of their sex life to chance ${ }^{(5)}$. They also reiterate the results of another study carried out with young Nigerians, in which adolescents with an internal locus of control were more likely to use condoms, whereas those with externalities assumed a higher-risk sexual behavior. The locus of control was not significant for age and sex ${ }^{(17)}$.

The adolescents presented higher External locus of control (Powerful Others), which corroborates the results of a study carried out with university adolescents in Lisbon, according to which the external control of locus is, on average, higher in girls than in boys, although difference was not significant ${ }^{(18)}$. However, this finding differs from that reported in studies with university adolescents in the state of São Paulo, in which young males presented greater External locus of control (Powerful Others)(9).

Studies show that certain personality characteristics contribute for adolescents to use or not contraceptive methods $s^{(11,17)}$ and that the External locus of control (Powerful Others) influences contraception ${ }^{(10)}$. In a study conducted with adolescents from Canoas City, state of Rio Grande do Sul, emotional aspects could interfere in the sex of young people who do not use condoms ${ }^{(19)}$.

In this study, the use of coitus interruptus was related to increased External locus of control (Chance) in their first sexual intercourse, perhaps because young people "did not think at the moment" and, in a way, did not take control, leaving the consequences to chance. The efficacy of coitus interruptus is known to be very low, but, because they believe they are using a contraceptive method, they infer that this can reduce the possibility of pregnancy ${ }^{(20)}$ but, in reality, they do not have the needed knowledge of this ${ }^{(21)}$.

In a study carried out in the countryside of São Paulo with university adolescents, when relating locus of control with knowledge and contraception, the adequate use of contraceptive methods was as smaller as higher externality was ${ }^{(9)}$. The adolescents who used some contraceptive in their first sexual relation presented greater External locus of control (Powerful Others). On the other hand, those who decided to use BCM only later presented, besides greater External locus of control (Powerful Others), a greater External locus of control (Chance). This indicates that the decision to use contraception in the first relationship may be influenced by other people, such as the parents and even the partner. The subsequent use of $B C M$, in addition to being influenced by other people, is due to the belief of chance as the main source of life control. Adolescents who used condoms in their first sexual intercourse showed greater internalization, evidencing a greater capacity for sexual negotiation with partners ${ }^{(9,22)}$. In another study, internal adolescents and with greater External locus of control (Powerful Others) had healthier dimensions of positive behaviors, which shows that health behavior is not correlated with beliefs in health being a matter of chance ${ }^{(23)}$.

Adolescents'knowledge of BCMs is extremely important because it generates contraceptive autonomy, favors the proper use of methods and, consequently, contributes to a healthy and safe life. However, although they have knowledge, they do not use it effectively in practice ${ }^{(11)}$. Thus, measures are needed to encourage the exercise of responsibility over their decisions, to favor the development of greater internalization, because this may contribute to new attitudes in terms of contraception, as already suggested in a previous study ${ }^{(9)}$. Research conducted in Lisbon with adolescents from higher education showed that responsible contraceptive practice makes sexual intercourse more pleasant ${ }^{(18)}$. Nonetheless, adolescents have problems managing their vulnerability in relationships and present contradictory behaviors in relation to their sexuality ${ }^{(24)}$.

\section{Study limitations}

One limitation of this study is related to the use of Levenson's multidimensional locus of locus scale, once it does not allow comparisons with other studies on the same theme because of them used two-dimensional scales. This difficulty was also observed in the study carried out with university students who used this same scale ${ }^{(9)}$.

\section{Contributions to Public Health}

To evaluate how the relations between the dimensions of the locus of control and the knowledge, attitude and the use of the pill and condoms contribute to high school adolescents their empowerment in the face of contraception. As a result, they gain more control over their actions and become more able to prevent both unplanned pregnancy and sexually transmitted infections. 


\section{CONCLUSIONS}

The dimensions of the locus of control are related to the contraceptive practice regarding the moment of initiation of BCM use and the use of condoms during the first sexual relation, and are related to sex, age and use of coitus interruptus, but have little or no relation to knowledge and attitude.
Internalization generally predisposes individuals to safer contraceptive practices and therefore the dimensions of locus of control can be considered in contraceptive-related interventions and developed through health education actions. Adolescents must feel welcomed and involved in the learning process and be encouraged to understand that unwanted pregnancy and the prevention of sexually transmitted infections can be controlled if they always use condoms.

\section{REFERENCES}

1. Vanzin R, Aerts D, Alves G, Câmara S, Palazzo L, Elicker E et al. Vida sexual de adolescentes escolares da rede pública de Porto Velho-RO. Aletheia [Internet]. 2013 [cited 2017 Jul 28];41(1):109-20. Available from: http://pepsic.bvsalud.org/pdf/aletheia/n41/n41a09.pdf

2. Chaves ACP, Bezerra EO, Pereira MLD, Wolfgang W. Conhecimentos e atitudes de adolescentes de uma escola pública sobre a transmissão sexual do HIV. Rev Bras Enferm [Internet]. 2014[cited 2017 Jul 28];67(1):48-57. Available from: http://www.scielo.br/pdf/reben/v67n1/00347167-reben-67-01-0048.pdf

3. Silva GS, Lourdes LA, Barroso KA, Guedes HM. Sexual behavior of adolescent students. Rev Min Enferm [Internet]. 2015[cited 2017 Jul 28];19(1):154-60. Available from: http://www.reme.org.br/artigo/detalhes/993

4. Tronco CB, Dell'Aglio DD. Caracterização do comportamento sexual de adolescentes: iniciação sexual e gênero. Gerais: Rev Interinst Psicol [Internet]. 2012[cited 2017 Jul 29];5(2):254-69. Available from: http://pepsic.bvsalud.org/pdf/gerais/v5n2/v5n2a06.pdf

5. Borges MR, Silveira RE, Santos AS, Lippi UG. Sexual behaviour among initial academic students. Rev Pesqui: Cuid Fundam [Internet]. 2015[cited 2017 Jul 28];7(2):2505-15. Available from: http://www.redalyc.org/html/5057/505750946027/

6. Silva LP, Camargo FC, Iwamoto HH. Comportamento sexual dos acadêmicos ingressantes em cursos da área da saúde de uma universidade pública. Rev Enferm Atenção Saúde [Internet]. 2014 [cited 2017 Jul 28];3(1):39-52. Available from: http://seer.uftm.edu.br/revistaeletronica/ index.php/enfer/article/view/929

7. Aquino OS, Brito FEV. Perfil sexual de adolescentes universitários de um curso de graduação em enfermagem. Rev Min Enferm [Internet]. 2012[cited 2017 Jul 28];16(3):324-9. Available from: http://www.reme.org.br/artigo/detalhes/534

8. Okpokumoku SE, Nwose EU, Nwajei SD. Sexual behaviour, knowledge and use of contraceptives among undergraduate students. Journal of Health Science Research [Internet]. 2017 [cited 2018 mai 03]; 2(2):10-7. Available from: http://www.informaticsjournals.com/index.php/jhsr/ article/view/18113

9. Alves AS, Lopes MHBM. Locus of control and contraceptive knowledge, attitude and practice among university students. Rev Saúde Pública [Internet]. 2010 [cited 2017 Jul 27];44(1):39-44. Available from: http://www.scielo.br/pdf/rsp/v44n1/04.pdf

10. Reese BM, Halpern CT. Attachment to Conventional Institutions and Adolescent Rapid Repeat Pregnancy: A Longitudinal National Study Among Adolescents in the United States. Maternal and Child Health Journal [Internet]. 2017 [cited 2018 May 01];21(1):58-67. Available from https://www.ncbi.nlm.nih.gov/pmc/articles/PMC5233596/

11. Almeida AC, Almeida AC, Costa MR, Firmo WCA. Conhecimento sobre a contracepção de emergência por adolescentes de uma escola pública de Lago Verde, Maranhão, Brasil. Rev UNINGÁ Review [Internet]. 2016[cited 2017 Jul 28];27(1):5-14. Available from: https://www. mastereditora.com.br/periodico/20160702_103201.pdf

12. Barbosa MLL. A relação entre o lócus de controle e o coping 'ações agressivas ': um estudo com atletas do esporte escolar. Prâksis[Internet]. 2016[cited 2017 Jul 29];7(1):27-36. Available from: http://www.redalyc.org/articulo.oa?id=525552631005

13. Instituto Brasileiro de Geografia e Estatística (IBGE). Pirâmide Etária [Internet]. 2010 [cited 2017 Jul 27]. Available from: http://www. censo2010.ibge.gov.br/sinopse/webservice/frm_piramide.php?codigo=315180

14. Snedecor WG, Cochram WG. Statistical Methods. 8.ed. lowa State: 1989.

15. Dela Coleta MF. Escala multidimensional de lócus de controle de Levenson. Arq Bras Psicol [Internet]. 1987[cited 2018 Jul 12];39(2):79-97. Available from: http://bibliotecadigital.fgv.br/ojs/index.php/abp/article/view/19592/18316

16. Cohen J. Statical Power analysis for the behaviour sciences. 2aed. New Jersey: Lawrence Erlbaum Associate: 1988. The significance of a product moment rs. p.75-108.

17. Pharr J, Enejoh V, Mavegam BO, Olutola A, et al. Relationship between Health Locus of Control and Risk Sexual Behaviors among Nigeria Adolescents. J AIDS Clin Res[Internet]. 2015 [cited 2018 Jun 24]; 6(6). Available from: https://www.ncbi.nlm.nih.gov/pmc/articles/ PMC4712957/

18. Janeiro JMSV, Oliveira IMS, Rodrigues MHG, Maceiras MJ, Rocha GMM. Sexual and contraceptives attitudes, the locus of health control and self-esteem among higher education students. Rev Bras Promoc Saude[Internet]. 2013 [cited 2017 Jul 27];26(4):505-12. Available from: https://periodicos.unifor.br/RBPS/article/view/3115

19. Chinazzo ÍR, Câmara SG, Frantz DG. Comportamento sexual de risco em jovens: aspectos cognitivos e emocionais. Psico-USF[Internet]. 2014 [cited 2018 Feb 08];19(1):1-12. Available from: http://www.scielo.br/pdf/pusf/v19n1/a02v19n1.pdf 
20. Ferreira MMSRS, Torgal MCLFPR. Life styles in adolescence: sexual behavior of Portuguese adolescents. Rev Esc Enferm USP [Internet]. 2011[cited 2018 Jun 24];45(3):589-95. Available from: http://www.scielo.br/pdf/reeusp/v45n3/en_v45n3a06.pdf

21. Molina MCC, Stoppiglia PGS, Martins CBG, Alencastro LCS. Conhecimento de adolescentes do ensino médio quanto aos métodos contraceptivos. Mundo Saúde [Internet]. 2015 [cited 2018 Jun 24];39(1):22-31. Available from: http://bvsms.saude.gov.br/bvs/periodicos/ mundo_saude_artigos/Conhecimento_adolescentes_ensino.pdf

22. Hosseini Z, Aghamolaei T, Ghanbarnejad A. Prediction of health promoting behaviors through the health locus of control in a sample of adolescents in Iran. Health Scope [Internet]. 2017[cited 2018 Jun 24];6(2):1-6. Available from: http://jhealthscope.com/en/articles/13126.html

23. Shabaraya, et al. Relationship between adolescents' health beliefs and health behavior. Int J Med Public Health [Internet]. 2011 [cited 2018 Jun 24];1(3):55-61. Available from: http://ijmedph.org/sites/default/files/IntJMedPublicHealth_2011_1_3_55_108481.pdf

24. Michielsen K, Remes P, Rugabo J, Rossem RV, Temmerman M. Rwandan young people's perceptions on sexuality and relationships: Results from a qualitative study using the 'mailbox technique'. J Soc Aspec HIV/AIDS [Internet]. 2014 [cited 2018 Jun 24];1(1):50-60. Available from: https://www.ncbi.nlm.nih.gov/pmc/articles/PMC4272159/ 